\title{
Transcriptional responses of Rosa rugosa to salt stress and salt shock
}

\section{Respostas transcricionais de Rosa rugosa ao estresse e choque salino}

\author{
Michele Valquíria dos Reis ${ }^{1 *}$ (D) , Laura Vaughn Rouhana² ${ }^{\mathbb{D}}$, Patrícia Duarte de Oliveira Paiva1 (D), \\ Diogo Pedrosa Correia da Silva ${ }^{1}$ (D), Renato Paiva ${ }^{3}$ (D), Schuyler Korban ${ }^{4}$ (D)
}

\author{
'Universidade Federal de Lavras/UFLA, Departamento de Agricultura/DAG, Lavras, MG, Brasil \\ ${ }^{2}$ Wright State University, Department of Biological Sciences, Dayton, OH, USA \\ 3Universidade Federal de Lavras/UFLA, Departamento de Biologia/DBI, Lavras, MG, Brasil \\ ${ }^{4}$ University of Illinois at Urbana-Champaign, Department of Natural Resources and Environmental Sciences, Urbana, Illinois, USA \\ ${ }^{*}$ Corresponding author: michele.reis@ufla.br \\ Received in May 26, 2020 and approved in October 21, 2020
}

\begin{abstract}
Rugosa rugosa has high tolerance to various stresses; however, the molecular mechanisms of this behavior under adverse conditions are unclear. The objective of this study is to investigate expression patterns of stress-related genes in response to salinity stress. Changes in transcript levels of $R$. rugose, grown under different salt stress conditions $(0,25,50$, and $100 \mathrm{mM} \mathrm{NaCl}$ ) over a long exposure period (30 days), have been investigated. In addition, the effects of salt shock stress on seedlings exposed to a high level ( $200 \mathrm{mM})$ of $\mathrm{NaCl}$ for a relatively short duration ( $3 \mathrm{~h}$ ) have also been investigated. Expression levels of selected differentially expressed genes have been determined using relative reverse transcription polymerase chain reaction (RT-PCR). It has been observed that seedlings exposed to salt stress for a long duration exhibited no signs of stress in both leaves and roots. In addition, expression of NHX1 in R. rugosa increased in the presence of NaCl. Furthermore, transcripts of EXP4, GPP, NHX1, NAC, and DREB genes also increased under high levels of $\mathrm{NaCl}$. In contrast, expression levels of MYB and TIR decreased during this salt shock treatment. Of particular interest is the increase in levels of transcripts of NHX1 in leaves of seedlings grown under both salt stress and salt shock conditions, thus suggesting that this gene plays an important role in salt stress tolerance in $R$. rugosa. These findings will support efforts in enhancing salt tolerance in roses, and perhaps in other members of the Rosaceae family.
\end{abstract}

Index terms: Rosaceae; salinity; salt tolerance; ion homeostasis.

\begin{abstract}
RESUMO
Rugosa rugosa tem alta tolerância a várias estresses; no entanto, os mecanismos moleculares dessa aptidão sob condições adversas não são claros. O objetivo deste estudo é investigar padrões de expressão de genes relacionados ao estresse em resposta a salinidade. Alterações nos níveis de transcrição de mudas de $R$. rugosa, cultivadas sob diferentes condições de estresse salino $(0,25,50$ e 100 mM de $\mathrm{NaCl}$ ) durante um longo período de exposição (30 dias), foram investigadas. Além disso, os efeitos do estresse por choque salino após a exposição das mudas a um nível alto $(200 \mathrm{mM})$ de $\mathrm{NaCl}$ por um período relativamente curto $(3 \mathrm{~h})$ também foram investigados. Os níveis de expressão de genes expressos diferencialmente selecionados foram determinados usando a reação em cadeia da polimerase com transcrição reversa relativa (RT-PCR). Observou-se que as mudas expostas ao estresse salino por um longo período não apresentaram sinais de estresse nas folhas e nas raízes. Além disso, a expressão de $\mathrm{NHX} 1$ em $R$. rugosa aumentou na presença de $\mathrm{NaCl}$. Além disso, os transcritos dos genes EXP4, GPP, NHX1, NAC e DREB também aumentaram em mudas cultivadas sob altos níveis de NaCl. Em contraste, os níveis de expressão de MYB e TIR diminuíram durante o tratamento com choque salino. De particular interesse é o aumento nos níveis de transcritos do NHX1 nas folhas de mudas cultivadas sob estresse e choque salino, sugerindo que esse gene desempenhe um papel importante na tolerância ao estresse salino em $R$. rugosa. Essas descobertas apoiarão os esforços para melhorar a tolerância ao sal nas rosas e, talvez, em outros membros da família Rosaceae.
\end{abstract}

Termos para indexação: Rosaceae; salinidade; tolerância; íon homeostase.

\section{INTRODUCTION}

Rosa rugosa Thumb., commonly known as rugosa rose or Japanese rose, is native to East Asia (Bruun, 2005). It is an important species for ornamental use in gardens, fragrance extraction, medicinal and food purposes, as well as a source of several valuable biological metabolites $(\mathrm{Na}$ et al., 2016; Olech; Nowak, 2012; Ren et al., 2018; Xie; Zhang, 2012; Zhang et al., 2019). Japanese rose is a salttolerant genotype capable of growing in naturally occurring sand dunes. Furthermore, Japanese rose grow most often on either sandy or gravel soils, but occasionally on other welldrained substrates, forming natural communities in sand 
dunes, shingle beaches, and on sea cliffs (Bruun, 2006). In European coastal areas, $R$. rugosa has been introduced for sand stabilization and for creating pathway boundaries, and it has also been used for ornamental purposes (Bruun, 2006; Hill et al., 2010). Interestingly, this species is considered as an invasive plant that is difficult to control in northern Europe due to its high competitiveness (Kelager; Pedersen; Bruun, 2013; Stefanowicz et al., 2019).

Wild-type R. rugosa has a higher level of resistance to salt stress than its cultivated forms, such as 'Ziyan', 'Purple Branch', and 'Zhongke 2' (Yang; Zhao; Xu, 2011). When treated daily with $0.25 \mathrm{~N} \mathrm{NaCl}$, plants demonstrated no injuries, and had the lowest $\mathrm{Na}$ and $\mathrm{Cl}$ contents in their leaves (Dirr, 1978). However, the mechanism underlying this observed salt stress tolerance in Japanese rose remains unclear. Gaining knowledge of the mechanism(s) of salt tolerance in plants is important for developing alternative solutions for salinity problems in agricultural crops (Reis et al., 2016; Bechtold; Field, 2018; Byrt et al., 2018; Figueiredo et al., 2017; Barros; Melo; Souza, 2019). Thus, the goal of this study is to investigate the molecular mechanism(s) of salt tolerance in $R$. rugosa salt tolerance by evaluating the effects of long exposure of young seedlings of $R$. rugosa to salinity stress and to salt shock on transcription profiles of a select stress-related genes.

\section{MATERIAL AND METHODS}

\section{Plant material and growth conditions}

Seeds of $R$. rugosa were stored in plastic bags containing sphagnum moss at $4{ }^{\circ} \mathrm{C}$, for a period of $\sim 3$ months for stratification, until germination. Subsequently, germinating seedlings were transferred to $15 \mathrm{~cm}$ (diameter) plastic pots containing Sunshine Mix, moved to the greenhouse, and grown under conditions of $25^{\circ} \mathrm{C} / 18^{\circ} \mathrm{C}$, day/night temperature, and $16 \mathrm{~h}$ of daylight.

\section{Salinity stress treatment}

To evaluate the effects of long exposure to salt stress, three-month-old seedlings were irrigated with a solution of either $0,25,50$, or $100 \mathrm{mM} \mathrm{NaCl}$ once every two days for a period of 30 days. A total of three plants (biological replicates) per treatment were used, and these were arranged in a completely randomized design. At the end of the experiment, leaves from the second nodes were collected, immediately frozen in liquid nitrogen, and then stored at $-80{ }^{\circ} \mathrm{C}$ until use.

For evaluation of salt shock, six-month-old plants, growing in the greenhouse, were irrigated with either 200
$\mathrm{mM} \mathrm{NaCl}$ or water (control). Three plants (biological replicates) per treatment were used, and these were arranged in a completely randomized design. After $3 \mathrm{~h}$ of treatment, leaves from the second nodes were collected, immediately frozen in liquid nitrogen, and stored at $-80{ }^{\circ} \mathrm{C}$ until use.

\section{RNA extraction and CDNA synthesis}

Leaf tissues were removed from the ultrafreezer, $10 \%$ polyvinylpyrrolidone was added, and then these tissues were ground into a fine powder. Total RNA was extracted from these ground leaf tissues using an RNase Plant Minikit (Qiagen, Doncaster, VIC, Australia), but with modifications. RNA was quantified using a NanoDrop ND-100 spectrophotometer (NanoDrop Technologies, Wilmington, DE). Total RNA from each sample was treated with DNase I (Invitrogen), and then used for cDNA synthesis. First-strand cDNA synthesis was performed with an Oligo (dt) primer using SuperScript III RT (Invitrogen).

\section{Quantitative Real-time PCR for expression analysis}

cDNA was diluted to $30 \mathrm{ng} / \mu \mathrm{l}$, and used for realtime PCR in 96-well plates in a 7300 real-time PCR system (Applied Biosystems, Foster City, CA). Realtime quantitative reverse transcription (qRT)- PCR was performed on three independent biological replicates, each containing three technical replicates, using a SYBR Green PCR Master Mix (Applied Biosystems). Genespecific primers from select stress-related genes, identified for real-time RT-PCR, were designed using the Primer 3 program (UNTERGASSER et al., 2012) based on BLAST consensus sequences from GenBank. Each reaction $(25 \mu \mathrm{l})$ contained $10.5 \mu \mathrm{l}$ water, $0.5 \mu \mathrm{l}$ of $200 \mathrm{nM}$ forward and reverse primers, $12.5 \mu 1$ of $2 \times$ SYBR Green I Master, and $5 \mu 1$ diluted cDNA. The amplification program consisted of one cycle of $95^{\circ} \mathrm{C}$ for 10 min followed by $95^{\circ} \mathrm{C}$ for 15 $\mathrm{s}$ and $60^{\circ} \mathrm{C}$ for $1 \mathrm{~min}$. Following amplification, a melting curve analysis was run using the program for one cycle at $95^{\circ} \mathrm{C}$ for $5 \mathrm{~s}, 65^{\circ} \mathrm{C}$ for $1 \mathrm{~min}$, and $95^{\circ} \mathrm{C}$ with a hold of 0 $\mathrm{s}$ in the acquisition step mode, followed by cooling at $4{ }^{\circ} \mathrm{C}$ for $10 \mathrm{~s}$. A negative control without a cDNA template was run with each analysis to evaluate the overall specificity. To normalize the total amount of cDNA in each reaction, select rose genes were co-amplified, as internal controls, using RhGADPH (EC589884) from R. hybrida (hybrid tea rose).

Data were analyzed using SDS software from a 7300 Real-time PCR system (Applied Biosystems) based on relative standard curves of PCR efficiency of target and reference genes. 
For the long duration salt stress exposure experiment, expression of the following stress-related genes, RhNAC, $R h N H X 1$, and RhEPX4, were investigated. Whereas, for the salt shock experiment, expression of the following stress-related genes, RhNAC, RhNHX, RhEPX4, RrGPP, $R h D R E B 1 B, \operatorname{RrMYB}$, and $R h T I R$, were investigated.

\section{RESULTS AND DISCUSSION}

\section{Long-term exposure to $\mathrm{NaCl}$}

Rosa rugosa originally grew in sand dunes. In the European coastal area, $R$. rugosa was planted for sand stabilization for pathway boundaries, and for use as an ornamental plant (Kelager; Pedersen; Bruun, 2013). As high soil salinity can occur naturally or human induced, it is important the introduction of good agricultural practices associated with the use of genotypes that are more tolerant to salinity soil conditions to alleviate salt stress problems. In fact, salt tolerant plant are well-adapted to such soil conditions, and their fitness enables them to re-establish osmotic and ionic homeostasis in response to salinity stress. It is these responses that will maintain the physiological and biochemical activities that will support plant growth under such stress environmental conditions.

In this study, the effects of salt stress on R. rugosa seedlings were investigated in order to develop a better understanding of the mechanism of salt stress on this plant. $R$. rugosa subjected to high salinity, for a relatively long exposure period of 30 days, were investigated. It was observed that none of the plants treated with different concentrations of $\mathrm{NaCl}$ showed signs of stress (Figure 1A and 1B). These results indicated that $R$, rugosa seedlings were indeed salt-tolerant to these varying levels of $\mathrm{NaCl}$. These findings were similar to observations reported in other rose genotypes subjected to different levels of salt stress (Niu; Rodriguez; Aguiniga, 2008).

It is known that salt stress tolerance is related to expression of stress-related genes in plants (Dai et al., 2012; Wang et al., 2016; Razzaque et al., 2019). To study the molecular mechanism(s) of salt stress tolerance in $R$. rugosa, qRT-PCR analysis of select stress-related genes, including $N A C, N H X 1$, and EXP4, has been conducted to identify patterns of gene expression in seedlings subjected to salt stress. It is found that transcript levels of $N A C$ are significantly higher in young plants treated with $\mathrm{NaCl}$ compared to those of control (Figure 1C). Among the three $\mathrm{NaCl}$ treatments, $N A C$ transcripts are higher in plants grown under $100 \mathrm{mM} \mathrm{NaCl}$, these are not significantly different from those grown under $25 \mathrm{mM}$ or $50 \mathrm{mM}$ (Figure 1C).
NAC proteins are involved in different biological plant events, such as development, as well as biotic and abiotic stress responses (Wang; Dane, 2013) Tobacco plants overexpressing DgNAC1 (Dendranthema grandiflorum $N A C$ ) have exhibited a markedly increased tolerance to salt (Liu et al., 2011). In this study, the observed high levels of expression of $N A C$ genes under $\mathrm{NaCl}$ treatments suggest that NAC transcription factors play important roles in salt stress tolerance and adaptation of rugosa rose.

Expression of $N H X 1$ increased significantly in $R$. rugosa young plants growning under salt stress conditions compared to those grown under control treatment (Figure 1C). Furthermore, NHX1 transcripts in plants treated with $25 \mathrm{mM}$ $\mathrm{NaCl}$ were 4-fold higher than that those detected in control seedlings. Moreover, $N H X 1$ transcripts in R. rugosa subjected to 50 and $100 \mathrm{mM} \mathrm{NaCl}$ were approximantely 16 -fold higher than those of control seedlings, respectively. These findings indicated that plants treated with higher concentrations of $\mathrm{NaCl}$ significantly increased expression levels of $\mathrm{NHXI}$ compared to those of control plants. Previously, it has been reported that a vacuolar $\mathrm{Na}^{+} / \mathrm{H}^{+}$antiporter gene in $R$. hybrida, $R h N H X 1$, demonstrated an increase in expression in the presence of $\mathrm{NaCl}$ (Kagami; Suzuki, 2005).

$\mathrm{The}^{\mathrm{Na}} / \mathrm{H}$ antiporter is a transmembrane transport protein that excludes $\mathrm{Na}+$ from the cytosol in exchange for $\mathrm{H}^{+}$intracellular $\mathrm{Na}^{+} / \mathrm{H}^{+}$. NHX proteins are wellknown plant cation/proton antiporters that are involved in $\mathrm{Na}^{+}$and $\mathrm{K}^{+}$compartmentalization into the vacuole, and play an important role in maintaining cellular $\mathrm{pH}$, $\mathrm{Na}^{+}$(compartmentalization), and $\mathrm{K}^{+}$(homeostasis) levels (Bassil et al., 2011; Pires et al., 2013). NHX is a salt tolerance determinant. This protein promotes ion homeostasis in saline environments. AtNHX proteins in Arabidopsis facilitate $\mathrm{Na}^{+}$ion compartmentalization and maintain the intracellular $\mathrm{K}^{+}$status. It has been reported that overexpression of NHX1 in rice, Arabidopsis, cumin, mungbean and soybean is correlated with salt tolerance in these plant species (Liu et al., 2010; Kumar et al., 2017).

In earlier studies, it has been observed that the sodium concentration in the medium positively correlates with the sodium absorption in roses (Lorenzo et al., 2000; Massa; Mattson; Lieth, 2008). Sodium is reported to play an important role in the stimulation of electrical conductivity $(\mathrm{Ec})$ in environments in which a high salinity level $(\mathrm{NaCl})$ occurs in the irrigation water source. As the sodium concentration increases, can promote an ion imbalance, especially of potassium (K) (Almeida; Oliveira; Saibo, 2017). Chrysanthemum morifolium 'Jinba' is less salt tolerant specie, that under salinity stress, showed lower $\mathrm{K}^{+} / \mathrm{Na}^{+}$ratio (Gao et al., 2016). 

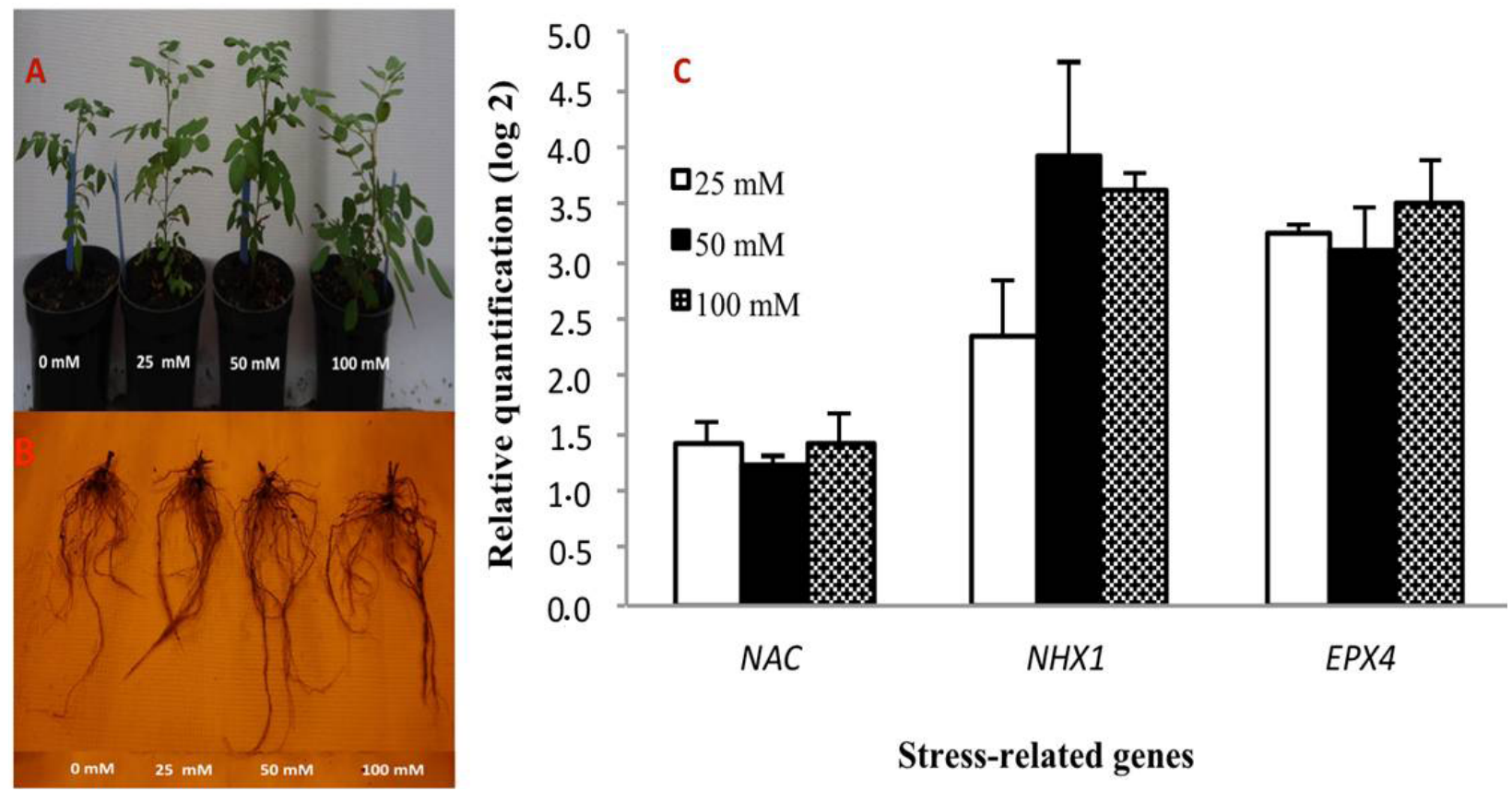

Figure 1: $R$. rugosa treated with various levels of $\mathrm{NaCl}$ for a period of 30 days. Shoot $(\mathrm{A})$ and root system (B). Relative quantification of gene expression in plants treated with different concentrations of $\mathrm{NaCl}(0,25,50$, and $100 \mathrm{mM})$.

In this study, expression levels of EXP4 significantly increased when rugosa seedlings were treated with $\mathrm{NaCl}$ compared to control treatment (Figure 1C). This suggested that the expansin gene in rugosa rose was highly expressed in response to salt stress treatments, and played similar roles to NAC transcription factors and NHX1 protein family in supporting plant growth and development under these salt stress conditions. Previously, it has been suggested that RhEXPA4 of R. hybrida conferred tolerance to abiotic stresses in Arabidopsis by modifying cell expansion and plant development (Lu et al., 2013). Additionally, RhEXPA4 was involved in the regulation of dehydration tolerance during rose petal expansion (Dai et al., 2012). Although, three other forms of expansins have been identified in $R$. hybrida, including RhEXP 1, 2, and 3 have been identified, RhEXP1 was reported to be involved in the expansion growth of rose petals (Takahashi et al., 2007). Expansin genes have been reported to be active in cell walls $(\mathrm{CWs})$, contributing their loosening and extension (Abuqamar et al., 2013). However, this group of genes have been observed to respond to different biotic and abiotic stresses, wherein cell wall-modifying proteins were reported to mediate plant acclimatization to biotic and abiotic stresses (Sasidharan; Voesenek; Pierik, 2011;
Chen et al., 2018). For example, Arabidopsis expansinlike A2 (EXLA2) has been identified to be involved in response to various biotic (necrotrophic pathogenesis) and abiotic (salt, cold, and abscisic acid [ABA]) stresses, while a mutant, exla2 Arabidopsis, was found to be more sensitive to stress (Abuqamar et al., 2013). Therefore, these earlier studies supported our finding in this study that expansins must have significantly contributed to rugosa rose seedlings responses to salt stress, and could be involved in signaling pathways regulating gene expression.

To ensure a plant's ability in tolerating and/ or adapting to salinity, stress tolerance and adaptation mechanisms, such as $\mathrm{Na}+$ vacuole compartmentalization, are very important, as this adaptation enables a plant to continue growing under conditions of salinity stress. When plants are exposed to salt, they would need to coordinate the expression of several genes to maintain $\mathrm{Na}+$ homeostasis.

\section{Salt shock}

Salt shock is an extreme form of salt stress following exposure to a high salt concentration by a single application of salt. As irrigation water may sometimes carry high levels of salt or excess fertilizer is used, it is 
very important to plant genotypes that can tolerate such stress conditions. In this study, a comparative experiment was conducted to evaluate salt shock treatment response of rugosa rose to $200 \mathrm{mM} \mathrm{NaCl}$ treatment for a period of $3 \mathrm{~h}$. This particular salt treatment and duration were selected as these conditions have been deemed the most responsive to stress. It has been reported that as sudden exposure to such levels of salt would induce osmotic shock, and deemed as the primary phase of stress (Shavrukov, 2013). Furthermore, under these conditions, plants would require a strong osmotic adjustment to survive the effects of such salt shock. Moreover, it has been reported that a second phase in this response is related to a gradual increase in ionic components (Shavrukov, 2013). Generally, plants would induce expression of different groups of genes in response to stress, including the following: 1) signal transduction (including genes encoding transcription factors), 2) enzymes, particularly those that respond to plant oxidation stress, 3) osmoprotectants, and 4) proteins related to water stress. Thus, in this study, a group of genes that would respond during salt shock, including expansins, phosphatases, and various other transcription factors (TFs), have been investigated.

Following a $3 \mathrm{~h}$ exposure to a salt shock treatment, rugosa rose demonstrated a two-fold increase in levels of EXPA4 gene expression, an expansin gene that responds to osmotic shock and plays a role in salt tolerance, than those grown under control conditions (Figure 2). It has been reported that $\beta$-expansin protein levels are found to higher in salt-resistant maize cultivars than in salt-sensitive cultivars (Geilfus et al., 2011). Furthermore, $\beta$-expansin transcript abundance is reported to be induced in Sorghum bicolor and Solanum tuberosum grown under salt and other stress (Buchanan et al., 2005; Chen et al., 2019).

Transcript abundance analysis of the gene encoding for galactose-1-phosphate phosphatase (GPP) showed a small increase in transcript levels following $3 \mathrm{~h}$ of salt shock (Figure 2). Previously, it has been reported that expression of some genes in response to osmotic shock can be registered within minutes of salt shock treatment (Shavrukov, 2013). Therefore, using a $3 \mathrm{~h}$ treatment in this study could have been rather long period of stress, and therefore, expression levels of GPP could have increased and then dropped down to normal levels. It is reported that GPP plays a central role in ABA biosynthesis in higher plants, as $\mathrm{ABA}$ is one of the most important and abundantly occurring water-soluble antioxidants in plants (Shavrukov, 2013). A few studies have demonstrated that exogenous applications of salicylic acid either via the rooting medium or via foliar sprays can alleviate salt stress (Arafa; Khafagy, 2009; Shalata; Neumann 2001). In addition, Arabidopsis mutants (ascorbate-deficient) are reported to more sensitive to salinity stress (Huang et al., 2005).

In this study, the $N A C \mathrm{TF}$ is found to be rapidly induced by salt shock stress treatment, as mRNA levels of RhNAC ( $R$. hybrida NAC) are found to increase after $3 \mathrm{~h}$ of this treatment (Figure 2). It has been previously reported that NAC is a stress-responsive $\mathrm{TF}$, and the gene ENAC1, encoding early NAC-domain protein induced by abiotic stress 1, has also been found to accumulate in the first hours following exposure to salt shock stress (Sun et al., 2012).

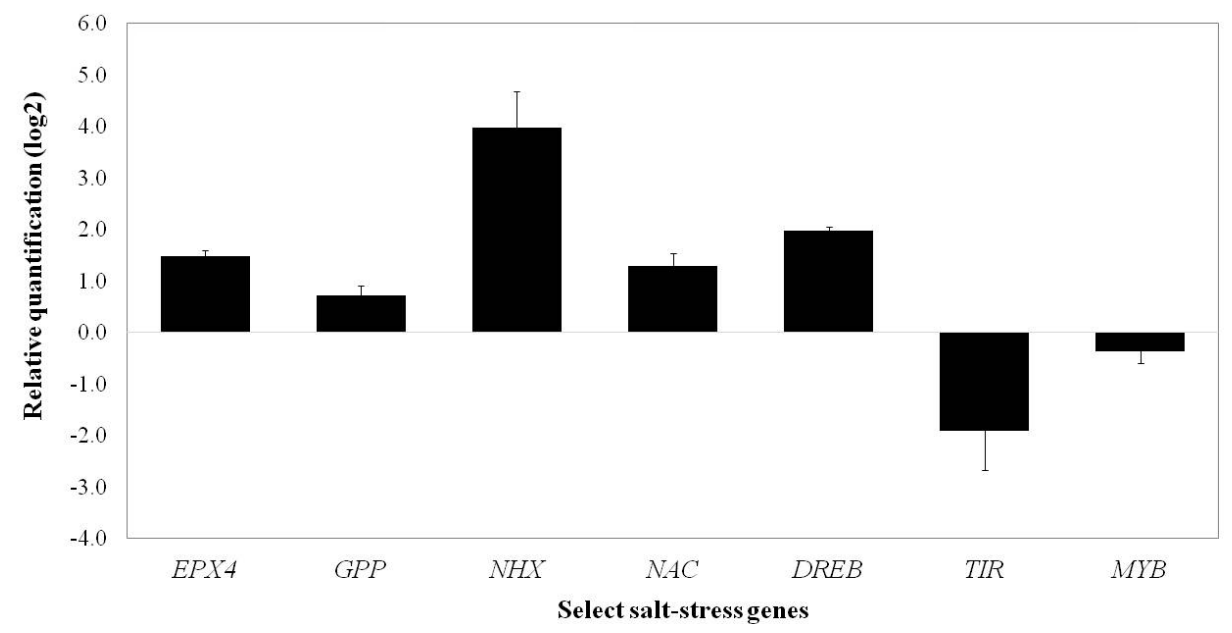

Figure 2: Relative quantification of gene expression in $R$. rugosa leaves during $3 \mathrm{~h}$ of salt shock stress using qRTPCR analysis. 
In this study, it is observed that $N H X 1$ demonstrated high levels of expression in rugosa rose treated with high concentrations of salt (salt shock) (Figure 2). It is reported that $\mathrm{Na}+\mathrm{H}+$ antiporters play important roles in compartmentalization of cytoplasmic $\mathrm{Na}+$ into vacuoles, and thereby their levels of expression increase in the presence of $\mathrm{NaCl}$ (Kagami; Suzuki, 2005). Therefore, findings in this study suggest that vacuolar $\mathrm{Na}+\mathrm{H}+$ antiporters are also involved in salt tolerance in rugosa rose, and they do play an important role during the first few hours of salt shock. Previously, it has been reported that AtNHX1 and AtNHX2 expression in Arabidopsis increase in response to high salt stress through an ABAdependent process. Additionally, these Arabidopsis $\mathrm{Na}^{+}$/ $\mathrm{H}^{+}$antiporters, NHX1 and NHX2, do in fact control vacuolar $\mathrm{pH}$ and $\mathrm{K}^{+}$homeostasis to regulate growth, flower development, and reproduction (Bassil et al., 2011). In other studies, it has been found that treatments with high concentrations of $\mathrm{NaCl}$ and $\mathrm{KCl}$ contribute to increases in transcript levels of NHX1 in roots and shoots (Mahasal; Chaopaknam; Ngampanya, 2011, Kumar et al., 2017).

When investigating yet another gene encoding for the DREB1 TF, it has been found that transcript levels of DREB1 have increased in rugosa rose flollowing salt shock treatment (Figure 2). DREB1 is an important TF that regulates various abiotic stress-responsive genes by activation of various downstream regulatory genes. Previous studies have demonstrated that LlaDREB $1 b$, in the perennial herb Lepidium latifolium, is induced by salt and drought stresses, and it is functional in an ABAindependent pathway (Gupta et al., 2013). Furthermore, overexpression of StDREB1 of potato increases salt tolerance in transgenic potato plants (Bouaziz et al., 2013). In addition, Arabidopsis plants overexpressing MsDREB2, isolated from Malus siverseii, have been found to be more tolerant to salt stress and to other abiotic stresses, including cold, heat, drought, and ABA (Zhao et al., 2013). Interestingly, these transgenic Arabidopsis plants have exhibited smaller stomatal apertures, reduced water loss, and higher levels of proline, thereby contributing to increased root growth and shoot growth (Zhao et al., 2013).

In this study, salt shock treatment on rugosa rose seedlings induced a drop in expression levels of the brp6 gene encoding for a putative for the TIR-NBSLRR resistance protein (Figure 2). This finding is similar to earlier reports wherein this gene is found to be downregulated in response to both drought and short-term salinity stress in Thellungiella halophila, a close relative halophyte of Arabidopsis, although it is upregulated over a long-period of stress (Gao et al., 2008). It is known that these genes are involved in various biotic and abiotic stresses, thus demonstrating the complex mechanism of stress response adaptation in plants (Wang et al., 2016; Banerjee et al., 2019).

Finally, transcripts of yet another TF investigated in this study, myb9 gene, are found to drop slightly in rugosa rose seedlings subjected to salt shock treatment (Figure 2). The MYB TF factor, as well as other TFs, including AP2/ERF, NAC, bZIP, MYC, WRKY, and Cys2/ His2-type zinc finger protein families can activate and repress many functional genes related to stress in response to environmental stresses (Golldack; Lüking; Yang, 2011; Shavrukov, 2013). Therefore, it is likely that myb9 may not play an important role in salt shock response in rugosa rose. Therefore, various other myb genes should be investigated in future studies to determine their potential roles in salinity shock responses in rose.

\section{CONCLUSIONS}

In this study, $R$. rugosa did not exhibit any salt injury symptoms after 30 days of salinity stress or $3 \mathrm{~h}$ of salt shock, thus suggesting that rugosa or Japanese rose has high levels of resistance to salinity stress. This observed tolerance of $R$. rugosa to salt stress may be related to high levels of expression of $\mathrm{NHX1}$ following exposure to long salt stress duration and to salt shock treatments. These findings contribute new knowledge to our understanding of salt stress tolerance in rose plants, and likely to other plants.

\section{ACKNOWLEDGEMENTS}

This study was supported in part by research funds provided by the Coordination for the Improvement of Higher Education Personnel (CAPES), the National Council for Scientific and Technological Development (CNPq), and the Research Support Foundation of the states of Minas Gerais (FAPEMIG), all in Brazil. In addition, research funding was also received from the Office of Research of the College of Agricultural, Consumer, and Environmental Sciences at the University of Illinois at Urbana-Champaign.

\section{REFERENCES}

ABUQAMAR, S. et al. A mutation in the expansin-like a2 gene enhances resistance to necrotrophic fungi and hypersensitivity to abiotic stress in arabidopsis thaliana. Molecular Plant Pathology, 14(8):813-827, 2013. 
ALMEIDA, D. M.; OLIVEIRA, M. M.; SAIBO, N. J. M. Regulation of $\mathrm{Na}+$ and $\mathrm{K}+$ homeostasis in plants: Towards improved salt stress tolerance in crop plants. Genetics and Molecular Biology, 40(1):326-345, 2017.

ARAFA, A. A.; KHAFAGY, M. A. The effect of glycinebetaine or ascorbic acid on grain germination and leaf structure of sorghum plants grown under salinity stress. Australian Journal of Crop Science, 3(5):294-304, 2009.

BANERJEE, A. et al. Salt acclimation differentially regulates the metabolites commonly involved in stress tolerance and aroma synthesis in indica rice cultivars. Plant Growth Regulation, 88:87-97, 2019.

BARROS, C. V. S. D.; MELO, Y. L.; SOUZA, M. D. F. Sensitivity and biochemical mechanisms of sunflower genotypes exposed to saline and water stress. Acta Physiology Plantarum, 41:159, 2019.

BASSIL, E. et al. The arabidopsis $\mathrm{Na}+/ \mathrm{H}+$ antiporters $\mathrm{NHX} 1$ and $\mathrm{NHX} 2$ control vacuolar $\mathrm{PH}$ and $\mathrm{K}+$ homeostasis to regulate growth, flower development, and reproduction. The Plant Cell, 23(9):3482-3497, 2011.

BECHTOLD, U.; FIELD, B. Molecular mechanisms controlling plant growth during abiotic stress, Journal of Experimental Botany, 69(11):2753-2758, 2018.

BOUAZIZ, D. et al. Overexpression of StDREB1 transcription factor increases tolerance to salt in transgenic potato plants. Molecular Biotechnology, 54(3):803-817, 2013.

BRUUN, H. H. Rosa rugosa thunb. Ex Murray. Journal of Ecology, 93(2):441-470, 2005.

BRUUN, H. H. Prospects for biocontrol of invasive rosa rugosa. Biocontrol, 51:141-181, 2006.

BUCHANAN, C. D. et al. Sorghum Bicolor's transcriptome response to dehydration, high salinity and ABA. Plant Molecular Biology, 58(5):699-720, 2005.

BYRT, C. S. et al. Root cell wall solutions for crop plants in saline soils. Plant Science, 269:47-55, 2018.

CHEN, L. et al. Tobacco alpha-expansin EXPA4 plays a role in Nicotiana benthamiana defence against Tobacco mosaic virus. Planta, 247(8):355-368, 2018.

CHEN, Y. et al. A comprehensive expression analysis of the expansin gene family in potato (Solanum tuberosum) discloses stress-responsive expansin-like B genes for drought and heat tolerances. PLoS One, 14(7):e0219837, 2019.
DAl, F. et al. RhNAC2 and RhEXPA4 are involved in the regulation of dehydration tolerance during the expansion of rose petals. Plant Physiology, 160(4):2064-2082, 2012.

DIRR, M. A. Tolerance of seven woody ornamentals to soilapplied sodium chloride. Journal Arboriculture, 4(7):162$165,1978$.

FIGUEIREDO, J. R. M. et al. Development changes in calla lily plants due to salt stress. Acta Physiology Plantarum, 39:147, 2017.

GAO, F. et al. Proteomic analysis of long-term salinity stressresponsive proteins in Thellungiella halophila leaves. Chinese Science Bulletin, 53(22):3530-3537, 2008.

$\mathrm{GAO}$, J. et al. Variation in tissue $\mathrm{Na}^{+}$content and the activity of SOS1 genes among two species and two related genera of chrysanthemum. BMC Plant Biology, 16:98, 2016.

GEILFUS, C. M. et al. Differential transcript expression of wallloosening candidates in leaves of maize cultivars differing in salt resistance. Journal of Plant Growth Regulation, 30(4):387-395, 2011.

GOLLDACK, D.; LÜKING, I.; YANG, O. Plant tolerance to drought and salinity: Stress regulating transcription factors and their functional significance in the cellular transcriptional network. Plant Cell Reports, 30(8):1383-1391, 2011.

GUPTA, S. M. et al. DRE-binding transcription factor gene (LlaDREB1b) is regulated by various abiotic stresses in Lepidium latifolium L. Molecular Biology Reports, 40(3): 2573-2580, 2013.

HILL, N. et al. Rosa rugosa as an invader of coastal sand dunes of cape breton island and mainland of Nova Scotia. Canadian Field-Naturalist, 124(2):151-158, 2010.

HUANG, C. et al. Increased sensitivity to salt stress in an ascorbate-deficient arabidopsis mutant. Journal of experimental botany, 56(422):3041-3049, 2005.

KAGAMI, T.; SUZUKI, M. Molecular and functional analysis of a vacuolar $\mathrm{Na}+/ \mathrm{H}+$ antiporter gene of Rosa hybrida. Genes \& Genetic Systems, 80(2):121-128, 2005.

KELAGER, A.; PEDERSENJ. S.; BRUUN, H. H. Multiple introductions and no loss of genetic diversity: Invasion history of japanese rose, rosa rugosa, in Europe. Biological Invasions, 15(5):1125-1141, 2013.

KUMAR, S. et al. Co-expression of arabidopsis NHX1 and bar improves the tolerance to salinity, oxidative stress, and herbicide in transgenic mungbean. Frontiers in Plant Science, 8:1896, 2017. 
LIU, H. et al. AtNHX3 Is a vacuolar $\mathrm{K}+/ \mathrm{H}+$ antiporter required for low-potassium tolerance in Arabidopsis thaliana. Plant, Cell and Environment, 33(11):1989-1999, 2010.

LIU, Q. et al. Overexpression of a novel chrysanthemum nac transcription factor gene enhances salt tolerance in tobacco. Biotechnology Letters, 33(10):2073-2082, 2011.

LORENZO, $\mathrm{H}$. et al. Effects of sodium on mineral nutrition in rose plants. Annals of Applied Biology, 137(1):65-72, 2000.

LU, P. et al. RhEXPA4, a rose expansin gene, modulates leaf growth and confers drought and salt tolerance to arabidopsis. Planta, 237(6):1547-1559, 2013.

MAHASAL, K.; CHAOPAKNAM, A.; NGAMPANYA, B. Expression analysis of $\mathrm{Na}+/ \mathrm{H}+$ exchanger and monosaccharide transporter genes in rice suspension cells under salt stress. Thai Journal of Agricultural Science, 44(5):125-128, 2011.

MASSA, D.; MATTSON, N. S.; LIETH, H. J. Effects of saline root environment $(\mathrm{NACl})$ on nitrate and potassium uptake kinetics for rose plants: A Michaelis-Menten modelling approach. Plant and Soil, 318(1-2):101-115, 2008.

NA, J. et al. Antistress effects of Rosa rugosa Thunb. on total sleep deprivation-induced anxiety-like behavior and cognitive dysfunction in rat: Possible mechanism of action of $5-\mathrm{HT}_{6}$ receptor antagonist. Journal of Medicinal Food, 19(9):870-81, 2016.

NIU, G.; RODRIGUEZ, D. S.; AGUINIGA, L. Effect of saline water irrigation on growth and physiological responses of three rose rootstocks. HortScience, 43(5):1479-1484, 2008.

OLECH, M.; NOWAK, R. Influence of different extraction procedures on the antiradical activity and phenolic profile of rosa rugosa petals. Acta Poloniae Pharmaceutica, 69(3):501-507, 2012.

PIRES, I. S. et al. Different evolutionary histories of two cation/ proton exchanger gene families in plants. BMC Plant Biology, 13:97, 2013.

RAZZAQUE, S. et al. Gene expression analysis associated with salt stress in a reciprocally crossed rice population. Scientific reports, 9:8249, 2019.

REIS, M. V. et al. Salinity in rose production. Ornamental Horticulture, 22(2):228-234, 2016.

REN, G. et al. Determination of the volatile and polyphenol constituents and the antimicrobial, antioxidant, and tyrosinase inhibitory activities of the bioactive compounds from the by-product of Rosa rugosa Thunb. var. Plena regal tea. BMC Complementary and Alternative Medicine, 18(1):307, 2018.
SASIDHARAN, R.; VOESENEK, L. A. C. J.; PIERIK, R. Cell wall modifying proteins mediate plant acclimatization to biotic and abiotic stresses. Critical Reviews in Plant Sciences, 30(6):548-562, 2011.

SHALATA, A.; NEUMANN, P. M. Exogenous ascorbic acid (Vitamin C) increases resistance to salt stress and reduces lipid peroxidation. Journal of Experimental Botany, 52(364):2207-2211, 2001.

SHAVRUKOV, Y. Salt stress or salt shock: Which genes are we studying? Journal of Experimental Botany, 64(1):119127, 2013.

STEFANOWICZ, A. M. et al. Invasion of Rosa rugosa Induced changes in soil nutrients and microbial communities of coastal sand dunes. Science of the Total Environment, 677: 340-349, 2019.

SUN, H. et al. ENAC1, a NAC transcription factor, is an early and transient response regulator induced by abiotic stress in rice (Oryza sativa L.). Molecular Biotechnology, 52(2):101110, 2012.

TAKAHASHI, R. et al. Analysis of the cell wall loosening proteins during rose flower opening. Acta Horticulturae, 755:48388, 2007.

UNTERGASSER, A. et al. Primer3: New capabilities and interfaces, Nucleic Acids Research, 4(15), e115, 2012.

WANG, Z.; DANE, F. NAC (NAM/ATAF/CUC) transcription factors in different stresses and their signaling pathway. Acta Physiologiae Plantarum, 35(5):1397-1408, 2013.

WANG, $\mathrm{H}$. et al. Recent advances in utilizing transcription factors to improve plant abiotic stress tolerance by transgenic technology. Frontiers in Plant Science, 7:67, 2016.

$\mathrm{XIE}, \mathrm{Y}$;; ZHANG, W. Antihypertensive ctivity of Rosa rugosa Thunb. flowers: Angiotensin I converting enzyme inhibitor. Journal of Ethnopharmacology, 144(3):562-566, 2012.

YANG, Z. Y.; ZHAO, L. Y.; XU, Z. D. Impacts of salt stress on the growth and physiological characteristics of Rosa rugosa. Journal of Applied Ecology, 22(8):1993-1998, 2011.

ZHANG, C. et al. Purification, characterization, antioxidant and moisture-preserving activities of polysaccharides from Rosa rugosa petals. International Journal of Biological Macromolecules, 124:938-945, 2019.

$\mathrm{ZHAO}, \mathrm{K}$. et al. Isolation and characterization of dehydrationresponsive element-binding factor 2C (MsDREB2C) from Malus sieversii Roem. Plant and Cell Physiology, 54(9): 1415-1430, 2013. 